

\title{
Penerapan Model Contekstual Teaching and Learning Berbasis Daring
}

\author{
Nurul Magfirah ${ }^{1 *}$, Rahmatia Thahir ${ }^{2}$, Anisa $^{3}$, Nurdiyanti $^{4}$, Muhammad Wadji ${ }^{5}$. \\ Program Studi Pendidikan Biologi, Fakultas Keguruan dan Ilmu Pendidikan, \\ Universitas Muhammadiyah Makassar \\ Nurul.magfirah@unismuh.ac.id
}

DOI: https://doi.org/10.32938/jbe.v6i2.1150

\begin{abstract}
Abstrak
Peningkatan hasil belajar dapat dilakukan dengan berbagai cara, salah satunya dengan penerapan model pembelajaran yang tepat salah satunya Contextual Teaching and Learning . Sejak pandemi covid 19 menyerang dunia, pembelajaran yang sebelumnya dilaksanakan secara offline tiba-tiba dilakukan secara daring dengan memanfaatkan teknologi. Meskipun secara daring model Contextual Teaching and Learning dapat diterapkan dalam pembelajaran daring dengan memanfaatkan media zoom meeting, google meeting, Google Classroom dan whattsap group. Penelitan ini bertujuan untuk mengetahui apakah ada pengaruh model Contextual Teaching and Learning yang dilaksanakan secara daring terhadap hasil belajar biologi mahasiswa Unismuh Makassar. Metode pada penelitian ini adalah jenis penelitian Quasi experiment dengan desain penelitian pretest-posttest control group design. Populasi penelitian ini adalah seluruh mahasiswa biologi Unismuh semester V dan sampel pada penilitian ini sebanyak 47 mahasiswa, yang terdiri atas 25 orang pada kelompom eksperimen dan 22 pada kelompok control. Penentuan sampel pada penelitian ini delakukan dengan teknik random sampling. Hasil penelitian menunjukan bahwa hasil analisis data uji hipotesis dengan menggunakan uji $t$ (independent-sample t test) diperoleh nilai Sig sebesar 0,006 dengan taraf signifikansi $(\alpha)$ adalah 0,05 , hal ini menunjukan bahwa nilai Sig lebih kecil dari taraf signifikasi $(\alpha)$ sehingga kesimpulan dalam penelitian ini adalah ada pengaruh pengaruh model pembelajaran Contextual Teaching and Learning yang diterapkan dalam pembelajaran daring terhadap hasil belajar Biologi mahasiswa Unismuh Makassar.
\end{abstract}

Kata Kunci: Hasil Belajar, CTL, Pembelajaran Daring

\begin{abstract}
Improving learning outcomes can be done in various ways, one of which is by applying the right learning model, one of which is Contextual Teaching and Learning. Since the Covid 19 pandemic attacked the world, learning that was previously carried out offline has suddenly been carried out online by utilizing technology. Although online the Contextual Teaching and Learning model can be applied in online learning by utilizing media zoom meetings, google meetings, Google Classroom, and WhatsApp group. This research aims to determine whether there is an effect of the Contextual Teaching and Learning model carried out online on the learning outcomes of Biology students at Unisumuh Makassar. The method in this research is a type of quasi-experiment research with a pretest-posttest control group design research design. The population of this research was all students of biology Unismuh semester $\mathrm{V}$ and the sample in this study was 47 students, consisting of 25 people in the experimental group and 22 in the control group. The samples in this study were determined by using a random sampling technique. The results showed that the results of the data analysis of hypothesis testing using the t-test (independent-sample t-test) obtained a Sig value of 0.006 with a significance level $(\alpha)$ of 0.05 , which indicates that the Sig value is smaller than the significance level $(\alpha)$. So the conclusion in this study is that there is an effect of the influence of the Contextual Teaching and Learning learning model applied in online learning on the learning outcomes of Biology students at Unismuh Makassar.
\end{abstract}


Keywords: Learning Outcomes, CTL, Online Learning.

\section{PENDAHULUAN}

Kemajuan kehidupan suatu bangsa sangat ditentukan oleh pendidikan. Pendidikan yang tertata dengan baik mampu menciptakan generasi yang berkualitas, cerdas, dan bermoral. Pendidikan merupakan unsur terpenting dalam usaha mencerdaskan kehidupan bangsa, sehingga pendidikan tidak terlepas dari usaha manusia untuk meningkatkan kepribadian dengan jalan membina potensi-potensi pribadi. Salah satu upaya yang dilakukan pemerintah untuk memperbaiki kualitas pendidikan adalah dengan mereview kurikulum lama untuk disesuaikan dengan perkembangan teknologi dan zaman. Menurut (Rusman, 2013) dunia Pendidikan saat ini tidak bisa terlepas dari semakin pesatnya perkembangan teknologi informasi, peningkatan mutu pendidikan disesuaikan dengan perkembangan teknologi berdasarkan tuntutan global dalam dunia Pendidikan.

Masa sekarang ini, dimana pandemi covid-19 masih berlangsung secara global termasuk di Indonesia. Meski dalam kondisi tersebut Pendidikan harus tetap berjalan dengan tidak mengesampingkan kualitas mutu pendidikan itu sendiri, sehingga para pendidik harus berperan aktif dan inovatif dalam melaksanakan pembelajaran. Situasi tersebut mengharuskan pendidik dan peserta didik tidak dapat bertatap muka secara langsung diruang kelas, untuk menghindari penularan covid, namun proses pembelajaran masih dapat di laksanakan dengan pembelajaran daring melalui memanfaatkan teknologi. Dimana menurut (Firman \& Rahayu, 2020) dengan penggunaan teknologi digital maka masih tetap memungkinkan mahasiswa dan dosen melaksanakan proses belajar mengajar meskipun berada di tempat yang berbeda.

Pembelajaran yang berlangsung secara daring seharusnya dirancang agar tetap terlaksana dengan baik dan tidak mengurangi keaktifan siswa dalam proses pembelajaran. Hal ini sejalan dengan pendapat (Marbun, 2021) yang menyatakan bahwa pembelajaran harus didesain agar terarah pada sistem pembelajaran yang mengarahkan mahasiswa untuk memiliki kemandirian, kreativitas, dan inovasi, sehingga kualitas pembelajaran terjamin.

Pembelajaran daring merupakan pembelajaran yang memanfaatkan jaringan internet dalam proses pembelajaran. Menurut (Kamilah et al., 2021) melalui pembelajaran daring ada banyak aplikasi yang dapat dimanfaatkan oleh pendidik dan peserta didik yaitu dapat melalui google meeting, zoom meeting, video conference untuk kegiatan tatap muka secara daring, kemudian ada juga aplikasi google classroom, edmodo, quiziz, whatsapp group dan lain sebagainya.

Sejak pandemi berlangsung pada awal tahun 2020, pembelajaran daring sudah dilaksanakan pada pembelajaran diseluruh dunia, termasuk di prodi Pendidikan Biologi Unismuh Makassar dengan memanfaatkan beberapa aplikasi melalui jaringan internet. Namun pembelajaran yang dilakukan hanya menggunakan pembelajaran langsung dengan metode ceramah melalui aplikai Google meet atau apalikasi Zoom, yang kadang dibantuk dengan aplikasi Google Classroom dan whatsapp group. Namun mahasiswa kurang aktif dalam mengikuti pembelajaran, Sebagian besar mahasiswa cenderung berdiam diri pada saat dosen menjelaskan materi kuliah, bahakan ada Sebagian yang meninggalkan room meet dengan alasan gangguan jaringan. Berdasarkan masalah tersebut dibutuhkan suatu model pembelajaran yang tepat diterapkan meskipun pembelajaran berlangsung secara daring, agar pembelajaran yang berlangsung lebih terarah karena model pembelajaran dapat memberikan gambaran bentuk pembelajaran dari awal sampai akhir kegiatan. Selain itu model pembelajaran juga merupakan rencana yang dapat digunakan untuk menyusun kurikulum (rencana pembelajaran jangka 
panjang), merancang alat dan bahan-bahan pembelajaran, berjalannya pembibingan pembelajaran dikelas dan lainnya. Model pembelajaran dapat menjadi acuan pemikiran, dalam artian setiap pendidik boleh menentukan model pembelajaran yang sesuai untuk mencapai tujuan Pendidikan (Adtman A. Hasan, 2019)

Model pembelajaran contextual teaching and learning (CTL) merupakan salah satu model pembelajaran yang tepat diterapkan pada materi biologi termasuk pada matakuliah Fisiologi Tumbuhan. Menurut (Latuconsina et al., 2017) model pembelajaran CTL merupakan model pembelajaran yang dapat membantu pendidik untuk mengaitkan materi dengan kehidupan nyata sehingga peserta didik mampu mengaitkan antara pengetahuan yang meraka peroleh dengan kehidupan sehari-harinya. Selanjutnya contextual teaching and learning merupakan model pembelajaran yang dapat menghubungkan antara kehidupan nyata dengan konten pelajaran, dan dapat mendorong peserta didik menghubungkan antara pengetahuan dan pengalaman yang didapatkan disekolah dengan kehidupan di lingkungan keluarga, masyarakat, dan dunia kerja (Sulfemi, 2019).

Menurut (Muhlisin et al., 2012), Pembelajaran contextual teaching and learning adalah sistem pembelajaran yang dapat merangsang otak untuk menyusun pola-pola untuk mewujudkan makna. Pendekatan pembelajaran kontekstual menempatkan siswa sebagai subjek pembelajaran, siswa yang berperan aktif dalam proses pembelajaran dengan menemukan dan mengeksplorasi pemahaman mereka sendiri tentang materi pelajaran. Guru / dosen menfasilitasi siswa untuk mengangkat benda-benda dalam kehidupan nyata, melalui tanya jawab, diskusi, inkuiri, sehingga siswa dapat mengkonstruk pengetahuannya dalam benaknya, pola tersebut akan sangat mempengaruhi kemampuan pemahaman siswa, (Purba \& Surya, 2020).

Berdasarkan uraian tersebut model pembelajaran CTL tersebut dapat di anggap sangat tepat diterapkan dalam pembelajaran secara daring. disamping Langkah-langkah pembelajaran dapat diterapkan melalui pembelajaran jarah jauh secara daring. CTL juga sangat tepat diterapkan pada materi Biologi termasuk mata kuliah Fisiologi Tumbuhan. CTR juga merupakan model pembelajaran dapat diterapkan untuk meningkatkan hasil belajar peserta didik hal ini sejalan dengan pendapat (L. Dewi \& Dwikoranto, 2021) dalam hasil penelitian beliau yaitu perolehan hasil penelitian dimana nilai rata-rata pretest yaitu sebesar 37. Sedangkan pada posttest nilai yang rata-rata yang diperoleh sebesar 83 dan rata-rata uji gain ternormalisasi sebesar 0,73. Dapat disempulkan bahwa dengan penerapan model pembelajaran Contextual Teaching and Learning (CTL) menunjukkan terjadinya peningkatan hasil belajar peserta didik pada pembelajaran fisika, daripada diterapkannya pendekatan pembelajaran konvensional, atas dasar ini juga sehingga peneliti mangangkat sebuah judul penelitian dengan judul Penerapan pembelajaran daring berbasis Cotextual.

\section{METODE PENELITIAN}

Penelitian ini adalah penelitian eksperiment semu (quasy experimental). Rancangan penelitian pemberian perlakuan pada variabel bebas untuk memperoleh gambaran pengaruhnya pada variabel terikat, tetapi variabel-variabel yang dapat berpengaruh lainnya tidak dapat dikontrol seutuhnya. Sampel pada penelitian ini terdiri atas dua yang mana salah satu sampel diberikan perlakuan yaitu penerapan model pembelajaran Contextual Teaching and Learning berbasis online dengan menggunakan aplikasi Google Meet dipadukan dengan video call whatshap, serta whatshap group, sementara kelas kontrol menggunakan aplikasi Google Meet untuk memberikan materi 
melalui ceramah dan diskusi dimana aplikasi ini merupakan aplikasi yang umum dan sudah sering digunakan dalam pembelajaran online. Dengan desain Pretest-Posttest Control Group Desain

Populasi dalam penelitian ini yaitu seluruh mahasiswa semester V Prodi Pendidikan Biologi FKIP Universitas Muhammadiyah Makassar sebanyak 70 orang yang terdiri dari 3 rombongan belajar. Teknik pengambilan sampel yang digunakan pada penelitian ini yaitu menggunakan teknik simple random sampling. Selanjutnya sampel pada penelitian ini yaitu mahasiswa semester V Prodi Pendidikan Biologi FKIP Universitas Muhammadiyah Makassar kelas 18A yang berjumlah 22 orang sebagai kelas kontrol dan kelas 18B yang berjumlah 25 orang sebagai kelas eksperimen.

Instrumen penelitian yang digunakan pada penelitian ini yaitu instrumen tes. Yaitu tes dalam bentuk soal essai dengan jumlah 10 nomor berdasarkan indikator capaian hasil belajar mahasiswa. Instrumen tes yang digunakan berupa tes objektif meliputi mengingat (C1), memahami (C2), menerapkan (C3), dan menganalisis (C4), mensintesis (C5), dan mengevaluasi (C6). Sebelum tes di ujikan, terlebih dahulu dikalibirasi instrumen berupa uji validitas instrumen tes, uji reliabilitas instrumen tes, indeks kesukaran instrumen tes, dan daya pembeda instrumen tes dilakukan. Selnjutnya tes tersebut di ujikan pada mahasiswa saat pretest dan posttest.

Data yang diperoleh dari kelas kontrol dan kelas eksperimen selanjutnya diolahagar dapat diketahui apakah ada pengaruh model pembelajaran Contextual Teaching and Learning terhadap hasil belajar mahasiswa pada matakuliah fisiologi tumbuhan. Teknik analisis data dilaukan dengan analisis statistik deskriptif dan analisis statistik inferensial

\section{HASIL DAN PEMBAHASAN}

Penelitian ini dilakukan pada dua kelas yang masing- masing kelas merupakan kelas control dan kelas eksperimen dengan perlakuan dengan model Contextual Teaching and Learning berbasis online . Kedua kelas pada sampel penelitian ini merupakan kelas yang bersifat homogen. Hal tersebut diketahui berdasarkan uji $t$-test berdasarkan nilai pretest. Data pada penelitian ini yaitu hasil pretest dan posttest yang dianalisis statistik deskriptif diperoleh nilai rata rata pada pretest kedua kelas homogen, sedangkan nilai rata-rata post-test pada kelas eksperiment lebih tinggi dari pada kelas kontrol.

Berikut adalah tabel hasil analisis statistik desktiptif dan inferensial :

Tabel 1. Data statistik deskrptif hasil belajar Biologi kelas kontrol dan kelas eksperimen

\begin{tabular}{lcccc}
\hline \multicolumn{1}{c}{ Statistik } & \multicolumn{2}{c}{ Kelas Kontrol } & \multicolumn{2}{c}{ Kelas Eksperimen } \\
\cline { 2 - 5 } Deskriptif & Pretest & Posttest & Pretast & Posttest \\
\hline Skor terendah & 33,95 & 51,25 & 33,95 & 62,50 \\
Skor tertinggi & 62,25 & 81,50 & 62,50 & 90 \\
Rata-rata & 45,39 & 67,71 & 46,36 & 75,39 \\
Standar Deviasi & 9,49 & 8,29 & 10,5 & 8,35 \\
\hline
\end{tabular}


Tabel 2. Distribusi Frekuensi dan Persentasi Nilai Hasil Belajar Biologi Sebelum diberikan perlakuan (Pretest)

\begin{tabular}{|c|c|c|c|c|c|c|}
\hline \multirow{2}{*}{ No. } & \multirow{2}{*}{$\begin{array}{c}\text { Interval } \\
\text { Nilai }\end{array}$} & \multicolumn{2}{|c|}{ Kelas Kontrol } & \multicolumn{2}{|c|}{$\begin{array}{r}\text { Kelas } \\
\text { Eksperimen }\end{array}$} & \multirow[t]{2}{*}{$\begin{array}{c}\text { Kategori } \\
\text { Hasil } \\
\text { Belajar }\end{array}$} \\
\hline & & Frekuensi & $\begin{array}{c}\text { Persentase } \\
(\%)\end{array}$ & Frekuensi & $\begin{array}{c}\text { Persentase } \\
(\%)\end{array}$ & \\
\hline 1. & $>81$ & 0 & 0 & 0 & 0 & Sangat baik \\
\hline 2. & $61-80$ & 2 & 9,09 & 4 & 16 & Baik \\
\hline 3. & $41-60$ & 8 & 36,37 & 9 & 36 & Cukup \\
\hline 4. & $21-40$ & 12 & 54,54 & 12 & 48 & Kurang \\
\hline \multirow[t]{2}{*}{5.} & $<20$ & 0 & 0 & 0 & 0 & $\begin{array}{l}\text { Sangat } \\
\text { Kurang }\end{array}$ \\
\hline & Jumlah & 22 & 100 & 25 & 100 & \\
\hline
\end{tabular}

Tabel 3. Distribusi Frekuensi dan Persentasi Nilai Hasil Belajar Biologi Setelah diberikan perlakuan (posttest)

\begin{tabular}{lcccccc}
\hline No. & $\begin{array}{c}\text { Interval } \\
\text { Nilai }\end{array}$ & Frekuensi & Persentase & Frekuensi & $\begin{array}{c}\text { Persentase } \\
(\%)\end{array}$ & $\begin{array}{c}\text { Kategori } \\
\text { Hasil } \\
\text { Belajar }\end{array}$ \\
\hline 1. & $>80$ & 3 & 13,64 & 5 & 20 & $\begin{array}{c}\text { Sangat } \\
\text { baik }\end{array}$ \\
2. & $61-80$ & 15 & 68,1 & 20 & 80 & Baik \\
3. & $41-60$ & 4 & 18,18 & 0 & 0 & Cukup \\
4. & $21-40$ & 0 & 0 & 0 & 0 & $\begin{array}{c}\text { Kurang } \\
\text { Sangat } \\
\text { 5. }\end{array}$ \\
\cline { 3 - 7 } & 20 & 0 & 0 & 0 & 0 & Baik \\
\hline \multicolumn{2}{c}{ Jumlah } & 23 & $100 \%$ & 25 & $100 \%$ & \\
\hline
\end{tabular}

Table 4 Kategori Hasil Rata-rata Nilai Uji N-gain

\begin{tabular}{ccc}
\hline Kelas & Nilai Rata-rata & Kategori \\
\hline Eksperimen & 0,55 & Sedang \\
Kontrol & 0,41 & Sedang \\
\hline
\end{tabular}

Pada penelitian ini, uji hipotesis dilakukan dengan bantuan program SPSS versi 25.0 dengan uji Independent Samples T Test. Dan uji hipotesis yang dihasilakan yaitu nilai signifikansi sebesar $0,003 \leq 0,05$. Berdasarkan hasil analisis data pada hasil penelitian memberikan gambaran bahwa pengetahuan awal mahasiswa pada kelas eksperimen maupun kelas kontrol sebelum diberikan perlakuan masih tergolong rendah. Hal tersebut digambarkan pada hasil analisis statistik data pretest pada tabel 1 yaitu nilai rata-rata untuk kelas kontrol yaitu 45,39 dan nilai rata-rata pada kelas eksperimen yaitu 46,36. data tersebut menunjukkan kedua kelas sebelum diberikan perlakuan memiliki kemampuan sama yang berada pada pada kategori rendah . 
Setelah proses pembelajaran dilaksanakan dan lakukan posttest untuk mengukur hasil belajar pada kedua kelas setelah pemberian perlakuan pada kelas eksperimen dan pada kelas control berjalan seperti pembelajaran sebelummnya. diperolehan nilai posttest dengan rata-rata untuk kelas eksperimen yaitu75,39 sedangkan nilai rata-rata pada kelas kontrol adalah 67,71. Hal ini menunjukkan bahwa Model pembelajaran Contextual Teaching and Learning berbasis Online dapat meningkatkan hasil belajar. Sedangkan Berdasarkan perhitungan data dengan analisis statistik terlihat nilai rata-rata kelas eksperimen lebih tinggi dibandingkan kelas kontrol.

Uji normalitas gain (N-Gain) dilakukan untuk mengetahui bagaimana selisih nilai posttest dan pretest pada kedua kelas tersebut. nilai rata-rata $\mathrm{N}$-Gain pada kelas eksperimen adalah 0, beda pada kategori sedang, sedangkan pada kelas kontor nilai ratarata $\mathrm{N}$-Gain adalah 0,41 yang berada pada kategori sedang. Hasil uji $\mathrm{N}$-Gain tersebut menunjukan adanya perbedaan selisih posttest dengan pretest pada kelas eksperimen dan kelas kontrol.

\section{Pembahasan}

Hasil penelitian ini memberikan gambaran setelah dilakukan analisis data bahwa kemampuan awal mahasiswa pada kelas yang memperoleh perlakuan (eksperimen) maupun kelas tanpa perlakuan (kontrol) sebelum diberikan perlakuan masih tergolong rendah. Hal tersebut terlihat pada hasil analisis statistik data pretest pada tabel 1 yaitu nilai rata-rata untuk kelas kontrol adalah 45,06, sedangkan nilai rata-rata untuk kelas eksperimen adalah 44,24. Dari data tersebut terlihat bahwa kedua kelas sebelum diberikan perlakuan memiliki kemampuan yang setara yaitu memiliki nilai yang masih pada kategori rendah. hal tersebut terjadi karena kedua sampel dalam penelitian ini belum pernah memperoleh materi Gerak pada Tumbuhan.

Selanjutnya setelah pembelajaran dilaksanakan, kemudian dilakukan posttest untuk mengukur hasil belajar setelah pemberian perlakuan kepada kelas eksperimen dan proses belajar mengajar pada kelas kontrol yang berjalan seperti biasanya tanpa perlakuan khusus. Perolehan nilai rata-rata pada hasil posttest untuk kelas eksperimen adalah 71,51 sedangkan nilai rata-rata yang didapatkan oleh kelas kontrol adalah 66,36. Hal ini menunjukkan bahwa Model pembelajaran Contextual Teaching and Learning berbasis Online dapat meningkatkan hasil hasil belajar. Sedangkan Berdasarkan perhitungan data dengan analisis statistik terlihat nilai rata-rata kelas yang mendapat perlakuan (eksperimen) lebih tinggi dibandingkan kelas tanpa perlakuan (kontrol). Selanjutnya dilakukan uji normalitas gain (N-Gain) untuk mengetahui bagaimana selisih nilai posttest dan pretest pada kedua kelas tersebut.

Hasil nilai rata-rata $\mathrm{N}$-Gain pada kelas eksperimen adalah 0,49 yaitu masuk ke dalam kategori sedang, sedangkan nilai rata-rata $\mathrm{N}$-Gain pada kelas kontrol adalah 0,39 dan masuk ke dalam kategori sedang namun dari data tersebut terlihat bahwa peningkatan nilai dari pretest ke posttest pada kelas eksperimen lebih tinggi dari pada kelas kontrol. Hasil uji N-Gain tersebut menunjukan adanya perbedaan selisih posttest dengan pretest pada kelas eksperimen dan kelas kontrol. Selanjutnya untuk menjawab hipotesis maka dilakukan uji $t$ (independent-Sample $t$ test) yang dilakukan pada nilai N-Gain kelas eksperimen dan kelas kontrol. Namu sebelum dilakukan uji hipotesis, terlebih dahulu dilakukan uji normalitas dan uji homogenitas pada kedua kelas. Data pretest dan posttest pada kelas eksperimen dan kelas control selanjutnya diuji dengan uji normalitas dan menunjukkan hasil bahwa data pretest dan posttest kedua kelas tersebut berdistribusi 
normal. Begitu juga dengan uji homogenitas yang telah dilakukan menunjukan bahwa data pretest dan posttest pada kelas kontrol maupun kelas eksperimen bersifat homogen. Hasil uji hipotesis yang dilakukan pada nilai rata-rata N-Gain kelas kontrol dan kelas eksperimen memperoleh nilai sig sebesar 0,006 lebih kecil dari nilai taraf signifikansi $(\alpha)$ yaitu 0,05 . Sehingga dapat disimpulkan bahwa ada pengaruh model pembelajaran Contextual Teaching and Learning berbasis online terhadap hasil belajar mahasiswa pada materi gerak pada tumbuhan.

Berdasarkan hasil penelitian dan analisis data, pembelajaran dengan model pembelajaran Contextual Teaching and Learning berbasis daring dapat berpengaruh positif terhadap hasil belajar mahasiswa. Hal ini disebabkan karena model pembelajaran Contextual Teaching and Learning berbasis online merupakan model pembelajaran yang dapat menghubungkan meteri pembelajaran dengan pengalaman kehidupan sehari-hari mahasiswa di lingkungan sekitar mereka. contoh pada materi gerak pada tumbuhan pada mata kuliag Fisiologi Tumbuhan, mahasiswa bisa memahami materi melalui pengamatan secara langsung bentuk gerak pada tumbuhan yang sering ditemukan dalam kehidupan sehari-hari dengan di dampingi oleh dosen secara virtual melalui video conference. Misalnya mahasiswa bisa mengamati secara langsung bentuk gerak pada tanaman putri malu dan apa yang menyebabkan tanaman putri malu tersebut bisa menutupkan daunnya. Hal ini sejalan dengan pendapat (Nursanti et all., 2020) yang mana beliau mengemukaka bahwa pada pembelajaran tematik pada muatan materi IPA kelompok eksperimen diberikan perlakuan melalui pendekatan Contextual Teaching and Learning berbasis Portofolio yang berlangsung dengan baik dan kondusif. Hal ini disebabkan pendekatan Contextual Teaching and Learning berbasis portofolio pembelajaran yang menghubungkan materi yang dibelajarkan dengan pengalaman atau kehidupan nyata siswa sehinnga siswa lebih mudah dalam memahami materi yang dipelajari dan mengambil manfaatnya serta dapat menerapkannya di kehidupan sehari-hari. Selain itu CTL juga melatih kemampuan siswa dalam mengambil keputusan, memecahkan masalah, berfikitr kreatif, melakukan perencanaann istruksional, implementasi rencana, mampu mengetahui sejauh mana mempertahankan pengetahuan mereka (Berns \& Erickson, 2001)

Misalnya pada materi hormone pada tumbuhan, dimana selama ini mahasiswa hanya mendengar bahwa tanaman sayur kelor jika dipangkas makan akan muncul cabang lateral yang lebih banyak sehingga menghasilkan daun yang lebih banyak untuk bisa dimanfaatkan sebagai sayuran. Namun dengan pembelajaran dengan model CTL mahasiswa dapat melakukan dan mengamati peristiwa tersebut secara langsung di lingkungan sekitar mereka dan memahami apa penyebab hal tersebut terjadi dan tetap dilakukan secara kelompok dan dibimbing oleh dosen melalui video conference. Dimana (Adim et al., 2020) mengemukakan bahwa Model pembelajaran kontekstual merupakan suatu model pembelajaran yang memberikan fasilitas kegiatan belajar siswa untuk mencari, mengolah, dan menemukan pengalaman belajar yang lebih bersifat konkrit melalui keterlibatan aktivitas siswa dalam mencoba, melakukan, dan mengalami sendiri. Meskipun secara daring penerapan model pembelajar CTL tetap dapat dilaksanakan dengan memanfaatkan jaringan internet dimana menurut (Surani, 2019) internet memiliki peran tersendiri yang dapat di manfaatkan dalam dunia pendidikan dan pendidikan di dunia, menurutnya telah banyak Pendidikan, pelatihan, dan pembelajaran yang telah memanfaatkan model pembelajaran berbasis internet yang lebih dikenal dengan online learning. 
Pembelajaran dengan model pembelajaran Contextual Teaching and Learning berbasis online . dapan dilakasanakan dengan pembelajaran berkelompok oleh mahasiswa melalui Video Conference untuk setiap kelompok yang setiap saat dapat di kunjungi oleh dosen dengan bergabung kedalam video conference setiap kelompok mahasiswa untuk membantau dan membimbing proses belajar setiap kelompok. Sehingga setiap anggota kelompok dapat diskusi bersama dalam menyelesaikan tugas kelompok sebelum di presentasikan di depan teman kelas melalui Google Meet atau zoom meeting. Dengan demikian mahasiswa tetap mampu mengemukan pendapat dan bertanya jika ada hal yang ingin di sampaikan atau belum di pahami. Sehingga dapat melatih kepercayaan diri setiap mahasiswa. Hal ini sejalan dengan pendapat (Aminah, 2021) yang menyatakan bahwa Contextual Teaching and Learning memiliki kelebihan yaitu dapat menguatkan rasa tanggung jawab dalam diri peserta didik, karena hasil dari tugas yang dikerjakan harus dipertanggungjawabkan di depan teman kelas dan guru, memupuk sifat mandiri pada diri peserta didik dengan tidak tergantung pada orang lain, mendorong peserta didik untuk semangat mengejar prestasi, menambah keaktifan dan kecakapan peserta didik, serta kebermaknaan setiap materi yang disampaikan, peserta didik mengetahui secara nyata penerapannya dalam kehidupan sehari-hari, pembelajaran lebih menyenangkan dan tidak membosankan dan terbentuk sikap kerja sama yang baik antar individu maupun kelompok.

Menurut (Sears, 2003) Pembelajaran kontekstual didasarkan pada hipotesis bahwa siswa cenderung mempertahankan pengetahuan dan keterampilan tingkat tinggi lebih lama Ketika mereka belajar pengalaman dibingkai oleh konteks yang sedekat mungkin kehidupan nyata. Pendekatan Contextual Teaching and Learning juga memberi kesempatan siswa untuk bekerjasama dalam kelompok, melatih berpikir kritis, melatih kepercayaan diri, menemukan dan memecahkan masalah yang diberikan atau yang ditemukan. Dengan membuat portofolio siswa dapat menilai hasil belajarnya sendiri dari waktu ke waktu, dengan begitu siswa dan guru dapat melihat perubahan pada diri siswa (Dewi. A. P. H, 2018). CTL juga dikatakan sebagai proses pembelajaran berjalan secara alamiah dalam bekerja dan mengalami sebagai bentuk kegiatan dari siswa, bukan peristiwa transfer pengetahuan dari pendidik ke peserta didik. Dan yang utama dalam pembelajaran ini adalah strategi dalam pembelajaran lebih penting dibandingkan hasil (Rahmawati et al., 2020)

Menurut (Hasrudin et al., 2015), Strategi Pengajaran dan Pembelajaran Biologi perlu diubah ke dasar pembelajaran kontekstual dimana siswa secara aktif membangun pengetahuannya sendiri, mampu berpikir kritis dan memiliki kemandirian dalam belajar. Tambahan, siswa perlu memiliki kecakapan hidup dan kemampuan untuk bekerja sama, kemampuan untuk berkomunikasi, kemampuan menjadi pembelajar yang rajin, dan mampu mengambil yang benar keputusan dalam memecahkan masalah kehidupan nyata. Oleh karena itu, dalam Pengajaran Biologi dan Kelas pembelajaran ada kebutuhan untuk mempelajari pendekatan inovatif yang sesuai.

Pada kegiatan diskusi kelompok yang dilakukan oleh mahasiswa , merupakan kegiatan yang dapan melatih kemampuan berpikir kreatif siswa dimana dengan berdiskusi dapat melatih siswa untuk berargument dan mengungkapkan pengetahuan stau apa yang merka pikirkan. Menurut (Bustami et al., 2018) tahapan CTL memungkinkan untuk mendorong keterampilan berpikir kritis. Dimana pada tahapan CTL seperti undangan dan eksplorasi merupakan tahap yang akan mendukung siswa untuk mengungkapkan pendapat awal 
mereka dalam kelompok sehingga mereka akan menjadi terlatih memberikan argumentasi tentang materi yang dipelajari dan mereka ketahui.

Hasil penelitian ini juga sejalan dengan (Arfan, H. Syam, 2020), Dari hasil penelitiannya menunjukkan penerapan model Contextual Teaching and Learning dapat meningkatkan keaktifan dan hasil belajar siswa pada mata pelajaran pembibitan tanaman perkebunan. Analisis kuantitatif menunjukkan hasil belajar pada test awal sebesar $5,88 \%$, pada siklus I terjadi peningkatan sebesar $66,70 \%$ dan kemudian pada siklus II menjadi 100\%. Hal ini berarti ada peningkatan hasil belajar siswa secara signifikan. Selanjutnya hasil penelitian (Apriliyani Diah Kartikasari, 2020) berdasarkan hasil observasi dan tes dapat disimpulkan bahwa Penerapan Model Pembelajaran Contextual Teaching And Learning (CTL) dalam pelajaran IPA materi perubahan wujud benda terbukti secara signifikan. Hal ini dapat dibuktikan bahwa kelas eksperimen setelah diberi perlakuan mengalami kenaikan dalam hasil belajar. (Dewi. P. Y. A \& Primayana, 2019) juga mengemukakan bahwa pengajaran dan dan pembelajaran kontekstual lebih tinggi daripada kelompok siswa yang belajar melalui model pembelajaran langsung.

\section{SIMPULAN DAN SARAN KESIMPULAN}

Berdasarkan hasil penelitian dan analisis data melalui uji hipotesis dengan menggunakan uji $t$ (independent-sample $t$ test) didapatkan nilai Sig sebesar 0,003 yang lebih kecil dari nilai tingkat signifikansinya $(\alpha)$ yaitu 0,05 , hal ini menunjukan bahwa nilai Sig lebih kecil dari nilai tingkat signifikasi $(\alpha)$. Hal tersebut dapat disimpulkan bahawa ada pengaruh Model Pembelajaran Contextual Teaching And Learning (CTL) berbasis online terhadap hasil belajar Biologi Mahasiswa Pendidikan Biologi Unismuh Makassar. Hal tersebut disababkan karena pada pembelajaran ini mahasiswa diberikan kesempatan untuk mengalami pembelajaran secara langsung dengan materi berkaitan dengan kehidupan sehari-hari dengan mengkomunikan pelajaran secara berkelompok.

\section{SARAN}

Model Contextual Teaching and Learning berbasis daring merupakan pembelajaran daring yang mengantarkan peserta didik untuk mengaitkan pelajarang dengan kehidupan nyata sehingga pembelajaran lebih bermakna. Sehingga disarankan untuk menerapkan pembelajaran CTL sebagai alternatif model pembelajaran yang dapat dilaksanakan selama pembelajaran daring dimas pandemic covid-19.

\section{REFERENSI}

Adim, M., Herawati, E. S. B., \& Nuraya, N. (2020). Pengaruh Model Pembelajaran Contextual Teaching and Learning menggunakan Media Kartu terhadap Minat Belajar IPA kelas IV SD. Jurnal Pendidikan Fisika Dan Sains, 3(1), 6-12.

Adtman A. Hasan. (2019). AL-Lisan : Jurnal Bahasa (e-Journal). 4, 133-147.

Aminah. (2021). UPAYA MENINGKATKAN MINAT DAN HASIL BELAJAR IPA MATERI POKOK PERPINDAHAN SUHU DAN KALOR MENGGUNAKAN MODEL PEMBELAJARAN CONTEXTUAL TEACHING AND LEARNING DI KELAS V SD NEGERI 101500 BATU. JIPDAS (Jurnal Lmiah Pendidikan Dasar), 1(1), 32-41. https://doi.org/10.4135/9781483318332.n86

Apriliyani Diah Kartikasari. (2020). Pengaruh Model Contextual Teaching and Learning Terhadap Hasil Belajar Siswa Mapel Ipa Materi Perubahan Wujud Benda the. Sittah: 
Journal of Primary Education, 1(1), 57-66.

https://www.jurnal.iainkediri.ac.id/index.php/sittah/article/view/2074

Arfan, H. Syam, H. N. (2020). Jurnal Pendidikan Teknologi Pertania n Penerapan Model Contextual Teaching and Learning pada Mata Pelajaran Pembibitan Tanaman Perkebunan untuk Meningkatkan Hasil Belajar Siswa Kelas XI ATP SMK Negeri 6 Takalar Application of Contextual Teaching and Learn. 6, 219-225.

Berns, R., \& Erickson, P. (2001). Contextual Teaching and Learning: Preparing Students for the New Economy. The Highlight Zone: Research (C) Work No. 5. The Highlight Zone Research, 5, 1-8.

Bustami, Y., Syafruddin, D., \& Afriani, R. (2018). The implementation of contextual learning to enhance biology students' critical thinking skills. Jurnal Pendidikan IPA Indonesia, 7(4), 451-457. https://doi.org/10.15294/jpii.v7i4.11721

Dewi, D. A. P. H. (2018). Pengaruh Pendekatan Contextual Teaching and Learning Berbasis Penilaian Portofolio Terhadap Kompetensi Pengetahuan Ipa. Journal for Lesson and Learning Studies, 1(3). https://doi.org/10.23887/jlls.v1i3.15387

Dewi, L., \& Dwikoranto, D. (2021). Analisis Pendekatan Pembelajaran Contextual Teaching and Learning (CTL) Terhadap Peningkatan Hasil Belajar Fisika dengan Metoda Library Research. PENDIPA Journal of Science Education, 5(2), 237-243. https://doi.org/10.33369/pendipa.5.2.237-243

Dewi, P. Y. A., \& Primayana, K. H. (2019). Effect of Learning Module with Setting Contextual Teaching and Learning to Increase the Understanding of Concepts. International Journal of Education and Learning, 1(1), 19-26. https://doi.org/10.31763/ijele.v1i1.26

Firman, F., \& Rahayu, S. (2020). Pembelajaran Online di Tengah Pandemi Covid-19. Indonesian Journal of Educational Science (IJES), 2(2), 81-89. https://doi.org/10.31605/ijes.v2i2.659

Hasrudin, Nasution, M. Y., \& Rezeqi, S. (2015). Application of contextual learning to improve critical thinking ability of students in biology teaching and learning strategies class. International Journal of Learning, Teaching and Educational Research, 11(3), 109-116. https://www.ijlter.org/index.php/ijlter/article/viewFile/317/158

Kamilah, A., Mugara, R., Ruqoyyah, S., \& Teaching, C. (2021). Pembelajaran Daring Membaca Permulaan Siswa Kelas 1 Sd Menggunakan Model Contextual Teaching and Learning Berbantuan Kartu Kata Learning in Basic School Students 'Start Reading Network Using the Contextual Teaching and Learning. IV(1), 218-226.

Latuconsina, N. K., Ika, A., \& Abrar, P. (2017). PENGARUH MODEL PEMBELAJARAN CONTEXTUAL TEACHING AND LEARNING (CTL) TERHADAP HASIL BELAJAR. $5(2), 70-75$.

Marbun, P. (2021). Disain Pembelajaran Online Pada Era Dan Pasca Covid-19. CSRID (Computer Science Research and Its Development Journal), 12(2), 129. https://doi.org/10.22303/csrid.12.2.2020.129-142

Muhlisin, A., Penelitian, P., Pascasarjana, P., \& Semarang, U. N. (2012). Pengembangan 
Perangkat Pembelajaran Ipa Terpadu Berbasis Contextual Teaching and Learning (Ctl) Dengan Model Pembelajaran Kooperatif Tipe Student Teams Achievement Division (Stad) Tema Polusi Udara. Journal of Educational Research and Evaluation, 1(2).

Purba, G. I. D., \& Surya, E. (2020). The Improving of Mathematical Understanding Ability and Positive Attitudes of Unimed FMIPA Students by Using the Contextual Teaching Learning (CTL)Approach. Journal of Physics: Conference Series, 1462(1). https://doi.org/10.1088/1742-6596/1462/1/012019

Rahmawati, S., Rohim, D. C., \& Kudus, U. M. (2020). Pengaruh Model Pembelajaran Kontekstual Berbasis Kearifan Lokal Terhadap Keterampilan Menyimak Siswa. 6(3).

Sears, S. (2003). Introduction to Contextual Teaching and Learning.

Sulfemi, W. . . N. y. (2019). Model Pembelajaran. 7(2), 73-84. https://doi.org/10.33603/ejpe.v7i2.1970

Surani, D. (2019). Studi Literatur: Peran Teknologi Pendidikan dalam Pendidikan 4.0. Prosiding Seminar Nasional Pendidikan FKIP, 2(1), 456-469. 